\title{
Alongamento vocálico e apagamento em coda medial nos desvios fonológicos $* * * *$
}

\author{
Vocalic lengthening and medial coda omission in phonological \\ disorders
}

Irani Rodrigues Maldonade*

Helena Bolli Mota**

*Fonoaudióloga. Pós-Doutoranda Bolsista Programa de Apoio a Projetos Institucionais com a Participação de Recém-Doutores (Prodoc) / Coordenação de Aperfeiçoamento de Pessoal de Nível Superior (Capes) do Programa de Pós-Graduação em Distúrbios da Comunicação Humana da Universidade Federal de Santa Maria (UFSM). Endereço para correspondência: Av. Princesa D'Oeste, 1055 - Apto. 94 - Campinas - SP CEP 13026-901 (iranirm@uol.com.br).

**Fonoaudióloga. Doutora em Linguística Aplicada pela Pontifícia Universidade Católica do Rio Grande do Sul. Professora Adjunta do Curso de Fonoaudiologia e do Programa de PósGraduação em Distúrbios da Comunicação Humana da UFSM

***Trabalho Realizado no Centro de Estudos de Linguagem e Fala da UFSM, Referente ao Desenvolvimento do Projeto de Prodoc/Capes do Programa de Pós-Graduação em Distúrbios da Comunicação Humana.

Artigo Original de Pesquisa

Artigo Submetido a Avaliação por Pares

Conflito de Interesse: não

Recebido em 12.11.2008

Revisado em 17.05.2009; 31.12.2009.

Aceito para Publicação em 01.02.2010.

\begin{abstract}
Background: phonological disorders. Aim: to verify the occurrence of vocalic lengthening, through acoustic analysis, in a group of 16 children ( 8 boys and 8 girls) with evolutive phonological disorders (EPD), who did not present in their speech $/ \mathrm{R} /$ and $/ \mathrm{S} /$ medial codas; to verify the occurrence percentage of lengthening and omission strategies in the two types of coda. Method: recordings of 16 children obtained through the presentation of a picture album representing the 18 pairs of words that contrast the syllabic structures $(\mathrm{C}) \mathrm{VC}$ and $\mathrm{CV}$. After transcribing the recordings, the pairs of words were submitted to acoustical analysis using PRAAT, version 4.4.16. Vowel duration was measured in both types of syllables. Statistical analysis was performed and the significance test (q-square) was applied considering $\mathrm{p}<0.05$. Results: although lengthening was not perceptually detected, it occurred in $93.75 \%$ of the analyzed samples. The q-square test indicated that the occurrence of lengthening is highly significant. Regarding the $/ \mathrm{R} /$ coda, results indicated $95.52 \%$ of lengthenings and $4.48 \%$ of omissions. For the $/ \mathrm{S} /$ coda, results indicated $12.5 \%$ of lengthenings and $87.5 \%$ of omissions. No significant statistical difference was observed between genders. Conclusion: acoustic analysis identified both vocalic lengthening and omission. Vocalic lengthening was more frequent in the $/ \mathrm{R} /$ coda; omission was more frequent in the $/ \mathrm{S} /$ coda. The child who presents lengthening seems to have the knowledge of the structure $(\mathrm{C}) \mathrm{VC}$ and, therefore, is closer to the production of the target-phoneme.
\end{abstract}

Key Words: Language; Speech; Language Development Disorders.

\section{Resumo}

Tema: desvios fonológicos. Objetivo: verificar a ocorrência do alongamento vocálico, pela análise acústica, num grupo de 16 crianças ( 8 meninos e 8 meninas) com desvios fonológicos evolutivos (DFE), que não apresentam na fala as codas $/ \mathrm{R} / \mathrm{e} / \mathrm{S} /$ mediais, além de levantar as porcentagens de ocorrência das estratégias de alongamento e apagamento nos dois tipos de coda. Método: gravação de 16 crianças mediante a apresentação de um álbum de figuras que representam 18 pares de palavras que contrastam as estruturas silábicas $(\mathrm{C}) \mathrm{VC}$ e CV. Após a transcrição, os pares de palavras foram submetidos à análise acústica pelo PRAAT, versão 4.4.16, para medir a duração das vogais nos dois tipos silábicos. Posteriormente, realizou-se a análise estatística dos dados e o teste de significância (qui-quadrado) foi aplicado, considerando-se $\mathrm{p}<0,05$. Resultados: embora nenhum alongamento tenha sido detectado perceptualmente, eles ocorreram em $93,75 \%$ da amostra. A aplicação do teste qui-quadrado revelou que tal ocorrência é altamente significativa. Para a coda /R/, registraram-se $95,52 \%$ de alongamentos e 4,48\% de apagamentos, enquanto que para a coda $/ \mathrm{S} /$, registraram-se $12,5 \%$ de alongamentos e $87,5 \%$ de apagamentos. Não houve diferenças significativas entre os gêneros. Conclusão: detectou-se, pela análise acústica, tanto o alongamento vocálico quanto o apagamento; o alongamento vocálico foi mais frequente na coda /R/ do que na /S/, o apagamento foi mais frequente na coda /S/ do que na coda /R/; a criança que apresenta o alongamento pode revelar conhecimento da estrutura $(\mathrm{C}) \mathrm{VC}$ e, portanto, estaria mais próxima da realização dos fonemas-alvo.

Palavras-Chave: Linguagem; Fala; Transtornos do Desenvolvimento da Linguagem.

Referenciar este material como: 


\section{Introduction}

In normal language acquisition, the phonological system is spontaneously acquired by children until the age of $4 / 51$. The syllabic structure (C)VC has later appearance, after $\mathrm{V}$ and $\mathrm{CV}$, not only in Brazilian Portuguese as well as in other Languages2-3. Children with evolutional phonological disorders (EPD) have difficulties in the organization of phonological system, producing many phonological processes. One of them is the omission of consonants (fricative, /S/ or non-lateral liquid, /R/) in medial coda position, what leads to the speech's simplification4. But, this is verified when the description is only based on investigator's perception (in other words, by hearing). With the acoustical analysis assistance, studies have been registered variation in the vowel duration as a form to evidence phonemic contrast56 , in such a way that it's possible to detect from the omission to the appearance of these phonemes in coda, other process: the vowel lengthening, imperceptible to the ears. It's an increase in the duration of the nuclear vowel, which preserves the temporal unity of the closed syllable by the fulfillment of the coda's time7.

The speech therapist attentive to the incorrect productions of the child looks to reflect about the new recourses to improve his practice. Thus, the objective of this study is to investigate the vowel lengthening occurrence in a group of children with EPD, that doesn't have the $/ \mathrm{R} /$ and $/ \mathrm{S} /$ medial codas, what will permit to verify if there's simply the omission or not and in what percentages of occurrence to each case. It will be also possible to characterize the vowel lengthening so that to contribute with speech therapy, examining the contexts where it occurs.

\section{Method}

The data's collect was done by the recording of children with EPD after their evaluation in the Speech's Sector of Therapist Service of Federal University of Santa Maria (UFSM).

The subjects were chosen for the research according to the following inclusions criteria:

\section{. To present EPD:}

- Not to present others disturbs (neurological, psychological, cognitive);

. To have normal hearing;

. Not to have undergone speech therapy before;

. The parents, duly elucidated about the research, have signed the Term of Free and Informed Consent, authorizing the children's participation.
16 children ( 8 boys and 8 girls), aged between 5 and 8 , were recorded individually. The sessions were recorded in acoustic cabin by the Mini Disc Sony MZ-R30 (with embedded microphone), placed at $15 \mathrm{cms}$ of distance from the child's mouth that was seated in front of the investigator. The excellent digital record was transferred from MD to the PC and converted to wav format, using the Digital Voice Recorder V2.0 program; that allowed the sound's acquisition in the PRAAT version 4.4.16.

The speech registers were got by naming (or delayed imitation of) pictures from a list of 18 pairs of words that contrast the $(\mathrm{C}) \mathrm{VC}$ and $\mathrm{CV}$, composed by: back x quotas; post x pot; beard x slaver; wide $\mathrm{x}$ lake; portage x pot; fence $\mathrm{x}$ drying; letter x search; march $\mathrm{x}$ male; tired $\mathrm{x}$ fact; spent $\mathrm{x}$ cat; grass $\mathrm{x}$ duck; little grass; small duck; line $\mathrm{x}$ rich; chew x stretcher; prism $\mathrm{x}$ cousin; right $\mathrm{x}$ arrow; wink $\mathrm{x}$ bite and little $\mathrm{x}$ pig.

The child, for example, should say "beard" when presented to the corresponding picture and, then, "slaver", according to the next picture of the album or persuaded by questions asked by the interviewer.

The data were transcribed and reviewed blindly and individually by two other researchers, posgraduation students at UFSM, with experience in acoustical analysis. After, the duration's acoustic measures were made using PRAAT, based on elaborated criterions from the wave's shape and the spectrogram, consisting the visual aspect the principal criterion to the cut decision of the acoustical segments, and hearing only used for confirmation. The duration's time of each vowel in milliseconds (ms) was obtained by measuring the wave sound from the beginning to the end of the formants.

The measures were made in opened syllables (the duration of /a/ in the first syllable of baba) and closed ones (the duration of $/ \mathrm{a} /$ in the first syllable of barba). The acoustical measures were made by the investigator. Then, the referred reviewers measured again the segments blindly and individually, getting two other measures. According to the criterion of the research, it was admitted the variation up to $20 \mathrm{~ms}$ among the researchers' measures. Since satisfied the criterion, the measures rates were calculated8. Divergences were solved by starting again all the measuring process and if the divergence persisted, the data was eliminated of the analysis. According to the criterion of the research, a vowel was considered lengthened when the duration value of the vowel in $(\mathrm{C}) \mathrm{VC}$ was up to $40 \mathrm{~ms}$ compared to the value of the vowel in CV.

It was assured that the record was concluded 
in just one session, to avoid any growth interference of the vocal tract that could modify the productions of children 9 .

The research project "The contribution of the acoustical analysis to the study of - normal and disturbed phonological acquisition" was registered under the number 064/2004 in the Research Ethics Committee, at the UFSM and approved before its development.

The data obtained by the acoustical analysis were submitted to the statistical analysis. It was used the q-square probabilistic test, with the significance level $\mathrm{p}$ ? 0,05.

\section{Resultados}

None vowel lengthening was detected perceptually as the reviewed transcriptions registered. However, high different picture as delineated after the acoustical analysis results.

From the 16 children records with EPD, 15 presented the vowel lengthening, corresponding to $93,75 \%$ of the sample. Fifteen presented the lengthening in $/ \mathrm{R} /$ and two in $/ \mathrm{S} /$, as observed in Graphic 1.

The q-square statistical test revealed that the occurrence of the vowel lengthening in the EPD group is significant.

Vowel lengthening in $/ \mathrm{R} /$ coda

There were 64 occurrences of vowel lengthening in $/ \mathrm{R} /$ coda, equivalent to $95,52 \%$. The difference between lengthening and not-lengthening is statistically significant, as evidenced by the q-square test, as p ? 0,0001.

Afterwards, the lengthening in $/ R /$ coda will be characterized in relation to the words it occurs; precedent consonantal phoneme; lengthened vowel (Table 1).

The most frequent lengthened words were: beard, corresponding to $19,70 \%$; followed by fence $(18,18 \%)$, then letter $(15,15 \%)$; pig $(12,12 \%)$ and wide $(7,58 \%)$. Other words appeared with percentages under $5 \%$. The q-square test revealed significant difference among the words, as $\mathrm{p}$ ? 0,0001.

In relation to the precedent consonantal phoneme to the vowel lengthening, it was verified that the phonemes $/ \mathrm{p} /, / \mathrm{b} /$ and $/ \mathrm{s} /$ occurred with the same frequencies, in other words, $19,70 \%$ each one; followed by $/ \mathrm{k} /(18,18 \%)$ and $/ 1 /$ and $/ \mathrm{m} /(7,58 \%)$. /f/ occurred with frequency under $5 \%$. The q-square test revealed significant difference among the phonemes, as $\mathrm{p}$ ? 0,0001 .
The most frequent lengthened vowels were: $/ \mathrm{a}$, that occurred with 48,48\%; then/e/ and/o/both with (19,70\%) and $/ ? /$ with $6,06 \%$./?/ occurred with frequency under $5 \%$. It was verified that $/ \mathrm{a} /$ was the most lengthened and also the one which presented the highest mean rate of duration measures (md); as long as /?/, less frequently lengthened, presented relatively high $\mathrm{md}(245 \mathrm{~ms})$. The q-square test revealed significant differences among the vowels and the mean rates of duration measures, as $\mathrm{p}$ ? 0,0001.

\section{Vowel lengthening in $/ \mathrm{S} /$ coda}

The number of lengthening in $/ \mathrm{S} /$ coda is lower than in $/ R /$ coda. The lengthening occurred just in two records equivalent to $12,5 \%$. The q-square test revealed that there aren'tsignificantstatistical differences between lengthening and not-lengthening. However, because of the sample's size, it may not be a totally reliable test, as the result signals.

Afterwards, the lengthening in $/ \mathrm{S} /$ coda will be characterized in relation to the words it occurs; precedent consonantal phoneme; lengthened vowel (Table 2).

There were three lengthened words and the most frequent lengthened one was post $(50 \%)$, then line $(33,33 \%)$ and grass $(16,67 \%)$. The q-square test showed no significant statistical differences among the words. However, it may not be a totally valid test according to the whole of data.

In relation to the precedent consonantal phoneme to the vowel lengthening, it was observed that $/ \mathrm{p} /$ occurred $66,67 \%$ and $/ \mathrm{r} / 33,33 \%$. The q-square test revealed that there are no significant statistical differences among the phonemes, but the whole of data must be considered.

In relation to the lengthened vowels, it was found that $/ ? /$ occurred $50 \%$; followed by $/ \mathrm{i} /(33,33 \%)$ and $/ \mathrm{a} /$ $(16,67 \%)$. It was verified that $/ ? /$ was the most frequent lengthened vowel and also the one which presented the highest $\mathrm{md}$. /i/ was more frequently lengthened than $/ \mathrm{a} /$ in $/ \mathrm{S} /$ coda, however presented lower md than la/. The q-square test shows that there are no significant statistical differences among the vowels and the mean rates of duration measures. But the accuracy of the test must be affected because of the size of the sample.

Crossing the gender variable

$/ \mathrm{R} /$ coda: from 15 records that the lengthened was verified, 7 were female (46,66\%) and 8 male $(53,33 \%)$. The Fisher test indicates that the variation found between the genders is not significant.

/S/ coda: from 2 records that the lengthened was verified, one was male $(50 \%)$ and one female $(50 \%)$. The Fisher test indicates that the variation found between the genders is not significant. 


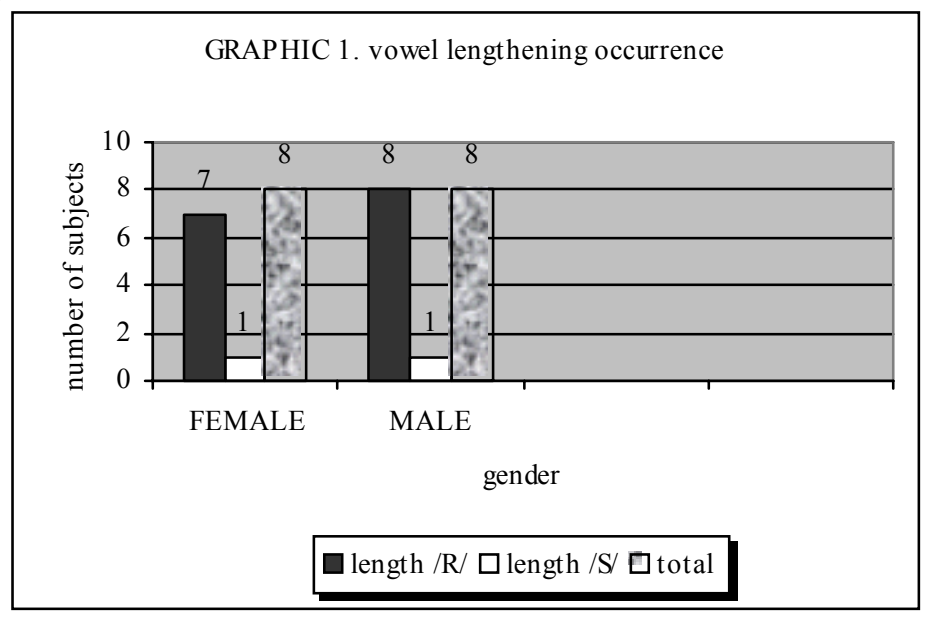

TABLE 1. Occurrences percentages of words, precedent consonantal phonemes and lengthened vowels in $/ \mathrm{R} /$ coda.

\begin{tabular}{|c|c|c|c|c|c|c|}
\hline Words & Percentages & Precedent Phonemes & Percentages & Vowels & Duration Mean Rates (ms) & Percentages \\
\hline beard & $19,70 \%$ & $/ \mathrm{p} / / \mathrm{b} / / \mathrm{s} /$ & $19,70 \%$ & $/ \mathrm{a} /$ & 280 & $48,48 \%$ \\
\hline fence & $18,18 \%$ & $/ \mathrm{k} /$ & $18,18 \%$ & /e/;/o/ & $222 ; 230$ & $19,70 \%$ \\
\hline letter & $15,15 \%$ & $/ \mathrm{m} / / 1 /$ & $7,58 \%$ & 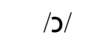 & 245 & $6,06 \%$ \\
\hline pig & $12,12 \%$ & $/ \mathrm{f} /$ & $<5 \%$ & $/ \varepsilon /$ & 184 & $3,03 \%$ \\
\hline wide & $7,58 \%$ & & & & & \\
\hline
\end{tabular}

Legend: $\%=$ occurrences percentages; $<=$ minor; $\mathrm{ms}=$ milliseconds.

TABLE 2. Occurrences Percentages of words, precedent consonantal phonemes and lengthened vowels in /S/ coda.

\begin{tabular}{|c|c|c|c|c|c|c|}
\hline Words & Percentages & Precedent Phonemes & Percentages & Vowels & Duration Means rate $(\mathrm{ms})$ & Percentages \\
\hline post & $50,00 \%$ & $/ \mathrm{p} /$ & $66,67 \%$ & 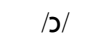 & 232 & $50,00 \%$ \\
\hline line & $33,33 \%$ & $/ \mathrm{r} /$ & $3,33 \%$ & /i/ & 164 & $33,33 \%$ \\
\hline grass & $16,67 \%$ & & & /a/ & 213 & $16,67 \%$ \\
\hline
\end{tabular}

Legend: \%: = occurrences percentages; $\mathrm{ms}=$ milliseconds. 


\section{Discussion}

Many authors show differences in the vowel duration related to the omission of final consonant in the (C)VC acquisition in English5-6. Perceptually, the omission of final consonant is identified, but when submitted to the acoustical analysis it's verified that the children mark the phonemic contrast of the omitted segment by the duration of the vowel: if the final omitted consonant is voiced, the vowel becomes longer and if the final omitted consonant is voiceless, the vowel becomes shorter. The results of this research allow concluding something in the same direction: although the children can not produce the medial /R/ and/or /S/ coda, they distinguish (C)VC from $\mathrm{CV}$ when the vowel is lengthened, filling all the complex syllable's time. Studies demonstrate that the vowel duration constitutes reliable parameter to mark phonemic distinction10-11.

The vowel's nature must be taken in account in vowels lengthening identification, as well as the phonological context where it appears12-13. Previous studies demonstrate that the low vowels are longer than the high ones; vowels with precedent voiced consonant are longer than those with precedent voiceless consonant; and the ones that have fricatives are longer than those that have plosives as precedents 12 . The results of this research agree only partially with these findings, because the most frequent precedent consonantal phonemes to $/ \mathrm{R} /$ coda were $/ \mathrm{p} /, / \mathrm{b} /, / \mathrm{s} /$ and then $/ \mathrm{k} /$ , and to $/ \mathrm{S} /$ coda it was $/ \mathrm{p} /$. To the vowels, it was found that $/ \mathrm{a} /$ was the most frequent lengthened in /R/ coda and also had the highest md, leading to agree with the results of previous studies. Further on, /?/ (vowel lower than /e/ and /o/) also presented higher md than /e/ and /o/ in /R/ coda, agreeing too with these results. However, /?/, vowel lower than /e/ and /o/ presented lower md than them in $/ \mathrm{R} /$ coda, therefore, contradicting the expected. In /S/ coda, /?/ presented higher md than /a/, that is the lowest vowel, contradicting the expected, as also had $/ \mathrm{p} /$ as the precedent consonantal phoneme, which is voiceless.

One of the security banks to delimitate the lengthening is concerned to the precedent consonantal phoneme: plosives allow the vowel segmentation easier than the fricatives. Mistakes in the vowels duration measures are referred in the phonemes transition zones. The magnitude of the mistake depends on the adjacent phonological context14.

Children with speech difficulties have limited vocabulary and/or sometimes also avoid complexes words, like polysyllables2. For this reason, the words analyzed in this study were disyllables. Other important reason to raise the most frequent precedent phonemes is related to the need of the professional in looking for facilitating words to the therapy. According to the results, the combination of occlusive and /a/ to the $/ \mathrm{R} /$ coda and the combination of occlusive and /?/ to /S/ coda can guide these selections.

Nowadays, anatomic changes are related to acoustic data in child development. Results indicate that the differences between genders are stressed in acoustic terms near the age of 4 until 8/9. In the researched group, there weren't significant differences between genders, in the two types of coda.

The acoustic analysis carried out prevents the interpretation that the not presentation of the final phoneme of the medial syllable (C)VC can just be seen as an omission. The lengthening occurrence in $/ R /$ coda was $95,52 \%$, in other words, it's a very frequent strategy. The omissions are only $4,48 \%$. But to /S/ coda, the lengthening occurrence was $12,5 \%$ and the omissions, $87,5 \%$. To describe the child speech accurately is a fundamental task to the speech therapist. It's suggested that the speech therapist evaluation must consider the possibility of verifying the vowel lengthening existence by the acoustic analysis support. Otherwise, it can be exposed to mistakes that can do all the difference in the therapeutic intervention15-16. This type of analysis is too safe and very suitable in the evaluation of the speech characteristics 17.

In relation to the lengthening had occurred more in $/ \mathrm{R} /$ coda than $/ \mathrm{S} /$, it adds that this trend also exists in the group of children with normal development, whose data were got spontaneously. Although the lengthening manifestation occurs between 18-23 months in the linguistic development for the two codas, the highest concentration to /S/ coda is at $18-23$, as to $/ \mathrm{R} /$ is at $24-35$ months 18 . It's affirmed that the $/ \mathrm{S} /$ in medial coda appears at the age of $2: 0$ and is acquired at 3:0, whereas the $/ \mathrm{R} / \mathrm{s}$ appearance occurs at 2:2 and is acquired at 3:1019.

In EPD group, it's observed both the omission (more frequent in $/ \mathrm{S} / \mathrm{coda}$ ) and the lengthening (more frequent in $/ \mathrm{R} /$ coda). Obviously, the distinction of the two processes strikes in the diagnostic accuracy. The children that present the vowel lengthening demonstrate to know the (C)VC structure and, for this reason, can be closer to the target-phoneme appearance than those who omit. Thus, the therapeutic program will require different 
strategies depending on the vowel lengthening identification or not15-21.

\section{Conclusion}

The acoustic analysis permitted to distinguish two processes in the EPD children's speech, when they don't present /R/ and /S/ in medial coda: the

\section{References}

1. Lamprecht RR. Sobre os desvios fonológicos. In: Lamprecht RR. (Org). Aquisição Fonológica do Português. Porto Alegre: Artes Médicas; 2004. p. 193-212.

2. Flipsen P. Syllabes per word in typical and delayed speech acquisition. Clinic. Linguist. Phon. 2006;20(4):293-301.

3. Ramos APF. Aquisição dos róticos em um dialeto do português brasileiro: discussão de aspectos fonéticos e fonológicos e suas implicações para a clínica fonoaudiológica. Rev. Soc. Bras. Fonoaudiol. 2000;4(6):31-5.

4. Keske-Soares M, Blanco APF, Mota HB. O desvio fonológico caracterizado por índices de substituição e omissão. Rev. Soc. Bras. Fonoaudiol.2004;9:10-8.

5. Weismer G, Dinnsen D, Elbert M. A study of voicing distinction associated with omitted word-final stops. J. Speech Hear. Dis. 1981 Aug; 320-28.

6. Maxwell E, Weismer G. The contribution of phonological, acoustic, and perceptual techniques to the characterization of misarticulating child's voice contrast for stops. Applied Psycholinguistics.1982;3:29-43.

7. Miranda AR. Evidências acústicas sobre a fixação do parâmetro da coda no português brasileiro. In: Hernandorena CLM. Aquisição de língua materna e de língua estrangeira. Aspectos fonético-fonológicos. Pelotas: Educat; 2001.

8. Pacheco V. Micro-prosódia segmental e estrutura silábica: o caso das oclusivas - dados preliminares. Inventário. Revista dos estudantes do Programa de Pós-Graduação em Letras e Linguística da UFBA. $3^{\text {a }}$ edição; 2005. Disponível em: http:/ /www.inventario.ufba.br/03.htm

9. Volperian HK, Kent RD. Vowel acoustic space development in children: a synthesis of acoustic and anatomic data. J. Speech Lang. Hear. Res. 2007 Dec;50(6):1510-45.

10. Luce PA, Charles-Luce J. Contextual effects on vowel duration, closure duration and the consonant/vowel ratio in speech production. J. Acoust. Soc. Am. 1985;78(6): 194957. omission and the vowel lengthening, instead of considering just exist the omission, when it's elected, exclusively, the perceptual analysis. The vowel lengthening occurred more in $/ \mathrm{R} /$ coda than /S/. The omission occurred more in /S/ coda than / $\mathrm{R} /$. The child that presents the vowel lengthening must be treated differently in therapy, because can reveal knowledge of $(\mathrm{C}) \mathrm{VC}$ structure and, therefore, must be closer to the target-phoneme appearance.

11. Neel AT. Vowel space characteristics and vowel identification accuracy. J. Speech Lang. Hear. Res. 2008 Jun;51(3):574-85.

12. Myers S. Vowel duration and neutralization of vowel length contrasts in Kinyarwanda. Journal of Phonetics. 2005;33:427-46.

13. Chen Y. The acoustic realization of vowels of Shanghai Chinese. Journal of Phonetics 2008;36:629-48.

14. Allen GD. Vowel Duration Measurement: A Reliability Study. J. Acoust. Soc. Am.1978;63(4):1176-85.

15. Mcleod S, Isaac K. Use of spectrographic analyses to evaluate the efficacy of phonological intervention. Clin. Linguist. Phon. 1994;9(3):229-34.

16. Forrest K, Weismer G, Elbert M, Dinnsen DA. Spectral analysis for target-appropriate $/ \mathrm{t} /$ and $/ \mathrm{k} /$ produced by phonologically disordered and normally articulating children. Clin. Linguist. Phon. 1994;8(4):267-81.

17. Pagan LO, Wertzner HF. Análise acústica das consoantes líquidas do Português Brasileiro em crianças com e sem transtorno fonológico. Rev. Soc. Bras. Fonoaudiol. 2007;12(2):106-13.

18. Maldonade IR, Mota HB, Mezzomo CL, Giacchini V, Dias RF. Investigações na aquisição da coda em PB em crianças com desenvolvimento normal de linguagem. Disponível em: http://www.sbfa.org.br/portal/anais2008/ anais

19. Mezzomo CL. Sobre a Aquisição da Coda. In: Lamprecht RR. (Org). Aquisição Fonológica do Português. Porto Alegre: Artes Médicas; 2004. p. 129-50.

20. Tyler AA, Edwards ML, Saxman JH. Acoustic validation of phonological knowledge and its relationship to treatment. J. Speech Hear. Dis.1990;55:251-61.

21. Stringfellow K, Mcleod S. Clinical exchange unsing a facilitating phonetic context to reduce an unusual form o gliding. Lang. Speech Hear.Service Schools. 1994;25:19193. 